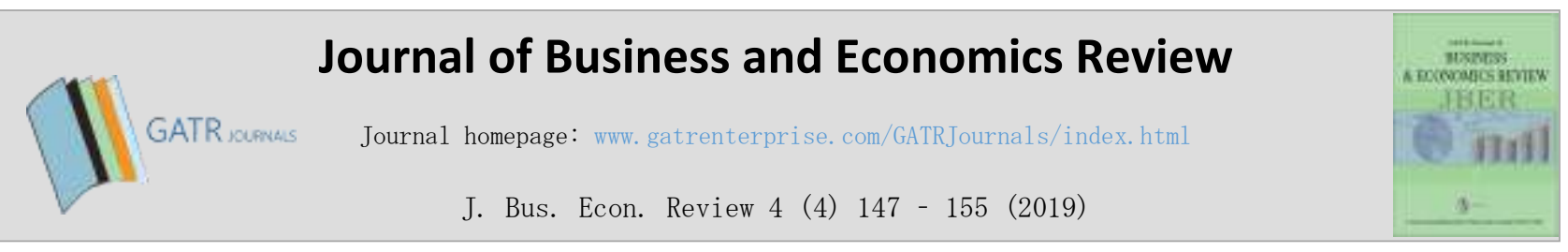

\title{
Financial Inclusion and Achievements of Sustainable Development Goals (SDGs) in Asean
}

\author{
Ahmad Ma' ruf ${ }^{1}$, Febriyana Aryani \\ ${ }^{1}$ Department of Economics, Universitas Muhammadiyah Yogyakarta, Yogyakarta, 55183, Indonesia \\ ${ }^{2}$ Institute of Public Policy and Economic Studies, Yogyakarta, 55293, Indonesia
}

\begin{abstract}
Objective - Financial Inclusion is an essential agenda at the ASEAN level. Increasing financial inclusion aims to develop the economic capacity of the population to reduce poverty and encourage income distribution. This study aims to analyze the relationship of financial inclusion to the achievement of Sustainable Development Goals (SDGs) in the aspect of poverty alleviation in ASEAN.

Methodology/Technique - This study uses a quantitative approach. The data used is secondary data in the period between 2010 and 2018. Data processing uses multiple regression. The financial inclusion dimensions analyzed are the socioeconomic dimension and the infrastructure dimension.

Findings - Financial Inclusion has a negative and significant relationship with the achievement of sustainable development goals (SGDs) in the aspect of poverty alleviation in ASEAN.

Novelty - The statement that the development of countries in ASEAN to realize SDGs on poverty eradication becomes very important. This study is essential for policymakers regarding poverty alleviation and financial inclusion development. This study contributes to the financial inclusion literature in ASEAN with an emphasis on the socioeconomic dimension.
\end{abstract}

Type of Paper: Empirical.

Keywords: Financial Inclusion; Sustainable Development Goals; Poverty; ASEAN.

Reference to this paper should be made as follows: Ma'ruf, A; Aryani, F. (2019). Financial Inclusion and Achievements of Sustainable Development Goals (SDGs) in Asean, J. Bus. Econ. Review, 4(4) 147 - 155 https://doi.org/10.35609/jber.2019.4.4(1)

JEL Classification: G00, G28.

\section{Introduction}

Development is a process of the amendment that includes various fundamental changes in social structure, attitudes of citizens, national institutions, economic growth, and all aspects of state life (Todaro \& Smith, 2017). Poverty is still the biggest obstacle to the development process because of the inability of the population to obtain sufficient income to meet their daily needs. One way the government can address this problem is to implement sustainable development (United Nations (UN) Sustainable Development Goals (SDGs) program, which has 17 goals and 169 targets (Suresh \& Johnson, 2015)). At SDGs, all objectives were interconnected, so success at one goal will solve problems at another (UNDP, 2016).

\footnotetext{
* Paper Info: Revised: September 12, 2019

Accepted: December 26, 2019

* Corresponding author: Ahmad Ma'ruf

E-mail: macrov_jogja@yahoo.com
} 
Affiliation: Department of Economics, Universitas Muhammadiyah Yogyakarta, Yogyakarta, 55183,

Indonesia

The success of development is characterized by an active and stable financial system (Demirguc-Kunt et. al. 2008, Sarma \& Pias, 2011). Construction of the financial sector will increase access and use of banking services by residents (Sarma \& Pias, 2011; Kuri \& Laha, 2015; Abdullahi \& Fakunmohu, 2017). Access to financial services is increasingly open, allowing citizens to increase their income through productive credit (Sarma \& Pias, 2011, Park \& Mercado, 2015).

Financial inclusion has become an influential agenda at the international and national levels. At the international level, financial inclusion was discussed in the G20, OECD, AFI, APEC, and ASEAN forums. The financial inclusion strategy arises because of the low financial access by the population resulting from low-income levels, the lack of knowledge of the community about finance and banking, bank administration costs, which are considered high, and the bank's reach far from residential areas. The goal of a financial inclusion strategy is to develop economic activities of the population that do not yet have access to financial services, to overcome the problem of poverty, and encourage income distribution.

Sustainable development is an essential condition for the success of a country. However, it is not enough if it is not followed by inclusive development (Ali \& Son, 2007; Neaime \& Gaysset, 2018). Inclusive development is defined as growth, which creates not only new economic opportunities but also guarantees equal access to opportunities created for all segments of the population, especially for the poor (Ali \& Son, 2007, Nanda \& Kaur, 2016). An inclusive financial system will increase the efficiency of financial services and the welfare of the population (Grohmann et. al. 2018, Neaime \& Gaysset, 2018).

Financial inclusion has an impact on poverty alleviation because the main problem facing the poor is limited financial access (Park \& Mercado, 2015). Therefore, financial inclusion will be the access provided to raise the poverty problem that exists in developing countries in ASEAN. Inclusive state finance can be triggered by various factors, such as socio-economic conditions, infrastructure, and banking (David et. al. 2018). Factors in socio-economic conditions include income per capita, financial literacy, unemployment, and the village population. Meanwhile, what is included in the infrastructure category can be the number of asphalt road networks, the number of internet users, the number of telephone users, the use of computers and newspapers. Next included in the category of reproduction is the amount of savings, deposits and credits, papers, and credit-deposit ratios. The purpose of this study is to analyze financial inclusion in achieving SDGs in ASEAN. The countries examined include Indonesia, Malaysia, the Philippines, Thailand, Brunei Darussalam, Cambodia, Singapore, and Myanmar, while Laos and Vietnam are not examined because of limited data access. The financial dimensions studied include socioeconomic factors with variable literacy rates and GDP per capita, and infrastructure factors with asphalt road variables.

\section{Methodology}

This study is quantitative. This study uses secondary data types in the form of time series data and crosssection periods between 2010 and 2018. The data collection technique is library research. The calculation of the financial inclusion index uses data on the number of deposit accounts, the number of financial services, the proportion of credit and savings to banks in ASEAN countries. This study uses several variables that affect financial inclusion, namely Literacy Rate, Infrastructure (Asphalt Road), and GDP Per Capita. An analysis of the relationship between variables is conduct3ed using multiple regression methods. Data quality testers use the classic assumption test.

\section{Results and Discussion}

\subsection{Financial Inclusion Index ASEAN}


The financial inclusion index consists of 3 dimensions, namely banking penetration, availability of banking services, and use of banking services. The average value of financial inclusion indexes of eight countries in ASEAN for the period 2010 to 2018 was 0.42 . This financial inclusion index is included in the medium category.

The inclusive financial index in ASEAN has a positive trend (Figure 1). The increase in the financial inclusion index in ASEAN is due to an increase in the value of each financial inclusion dimension. An increase in the financial inclusion index indicates an increase in access and use of banking services by the population. This is in line with the development of the banking sector in ASEAN.

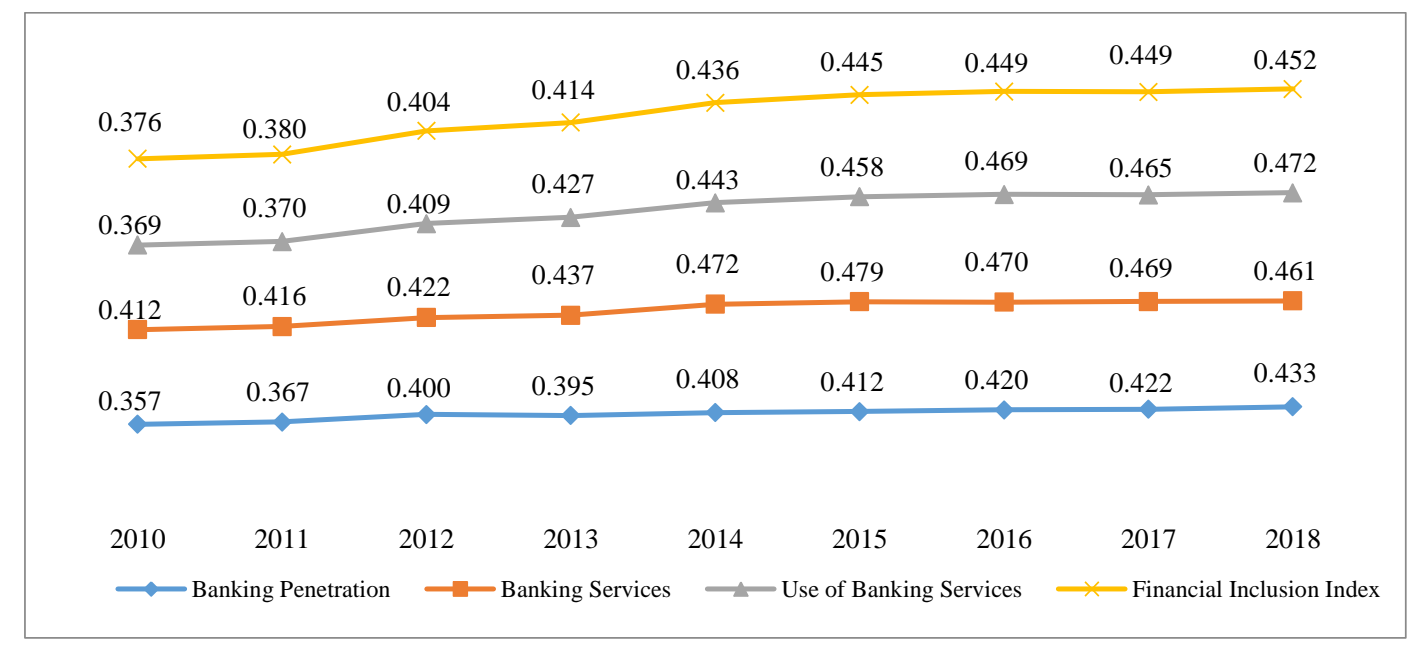

Figure1. Financial Inclusion Index in ASEAN and its Dimensions 2010-2018

The average value of each dimension of the formation of a financial inclusion index in ASEAN is included in the Medium category. The availability of banking services has the highest value compared to the dimensions of banking penetration and the dimension of the use of banking services, which ranges from 0.369 to 0.472 . This indicates positive growth in the number of banking branches in ASEAN. The more bank branches, the higher the population's opportunity to reach financial services. The availability dimension is due to the continued development of infrastructure in ASEAN countries.

The dimensions of the use of banking services are lower than the aspects of the availability of banking services. The dimensions of the use of banking services are in the moderate category, with an average index score of 0.43. In the period 2010-2018, the use of banking services by the ASEAN population has increased. This increased dimension shows an increase in the volume of savings collected, which has implications for the rise in credit by banks in ASEAN.

Of the three dimensions, the dimension of banking penetration has the lowest value compared to the dimensions of the availability of banking services and the dimensions of the use of banking services ranging from 0.357 to 0.433 . This means that the majority of the population in ASEAN accessing banking services is still relatively low. 


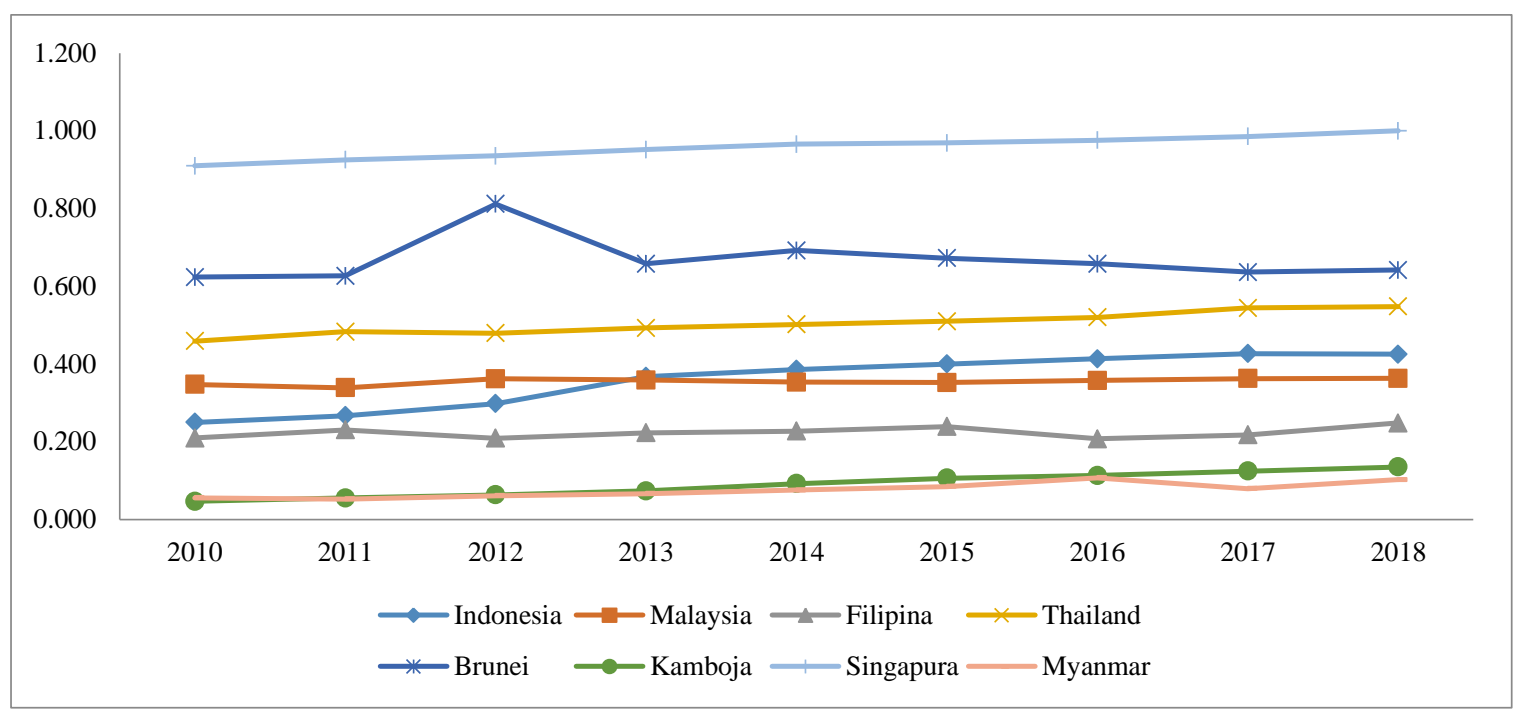

Figure 2. Trend of Financial Penetration Dimensions in ASEAN in 2010-2018

There are three countries in ASEAN that have banking penetration indexes with high categories, and there are three countries classified as low categories (Figure 2). The positive trend of banking penetration index shows an increase in the use of banking services by the population in ASEAN. The increase in the value of the penetration index can also be caused by the rise in the number of individual accounts. Singapore has the highest penetration index compared to other countries. The high penetration of banks in Singapore is related to the size of Singapore's economy.

Myanmar has a low banking penetration. Increasing the number of the adult population if not followed by an increase in the name of depositors makes the dimension of financial penetration low. The value of Myanmar's penetration dimensions ranges from 0.05 - 0.1 .

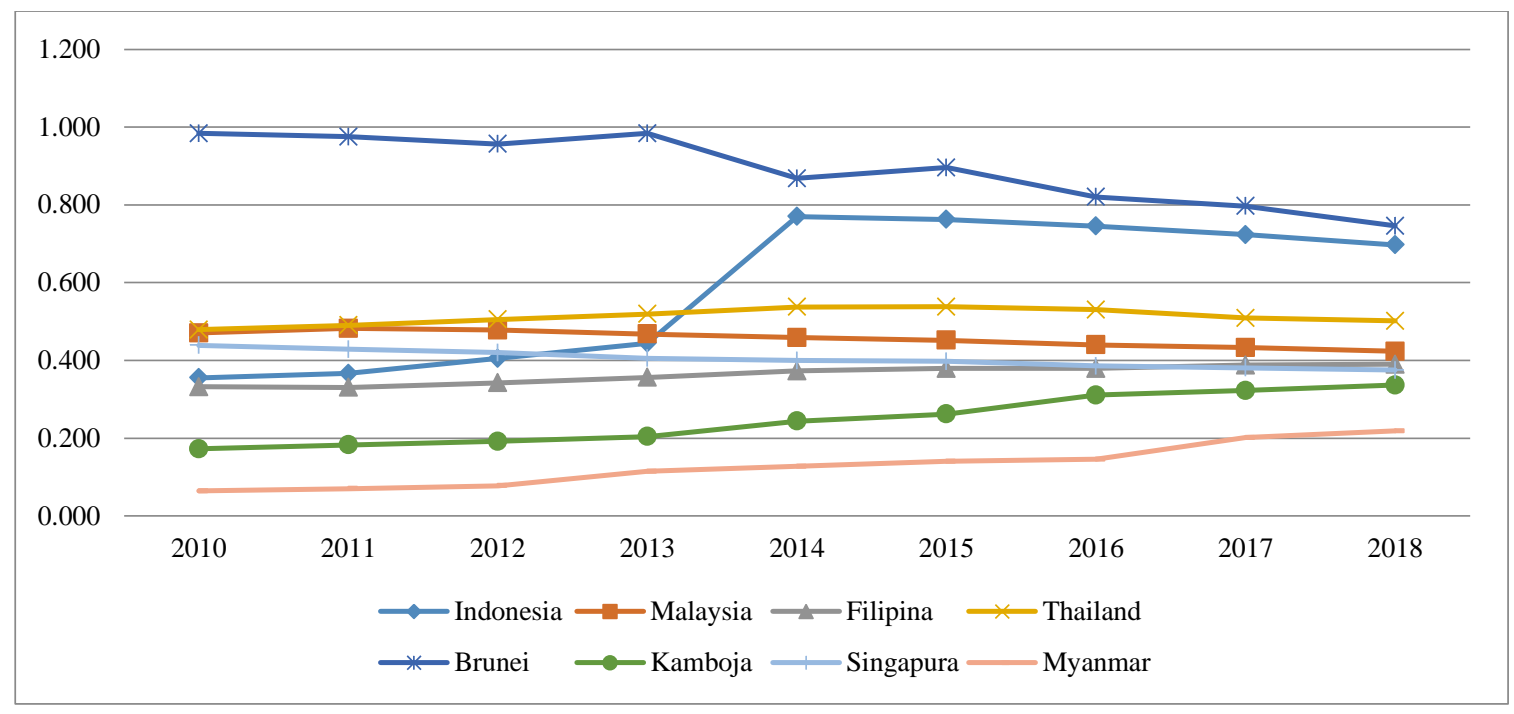

Figure 3. Dimensions of the Availability of Banking Services in ASEAN in 2010-2018

ASEAN countries have the dimensions of availability in the medium category, between 0.3-0.6 (Figure 3). Countries that have high availability dimension values are Brunei with dimension values above 0.6. The country with the lowest availability dimension is Myanmar, with an amount of 0.06-0.2. The number of 
branch offices of a state is related to the number of banking service users. The number of branch offices is not enough to describe the wide distribution of banking services, so the ratio is used is the number of branch offices divided by the name of the adult population.

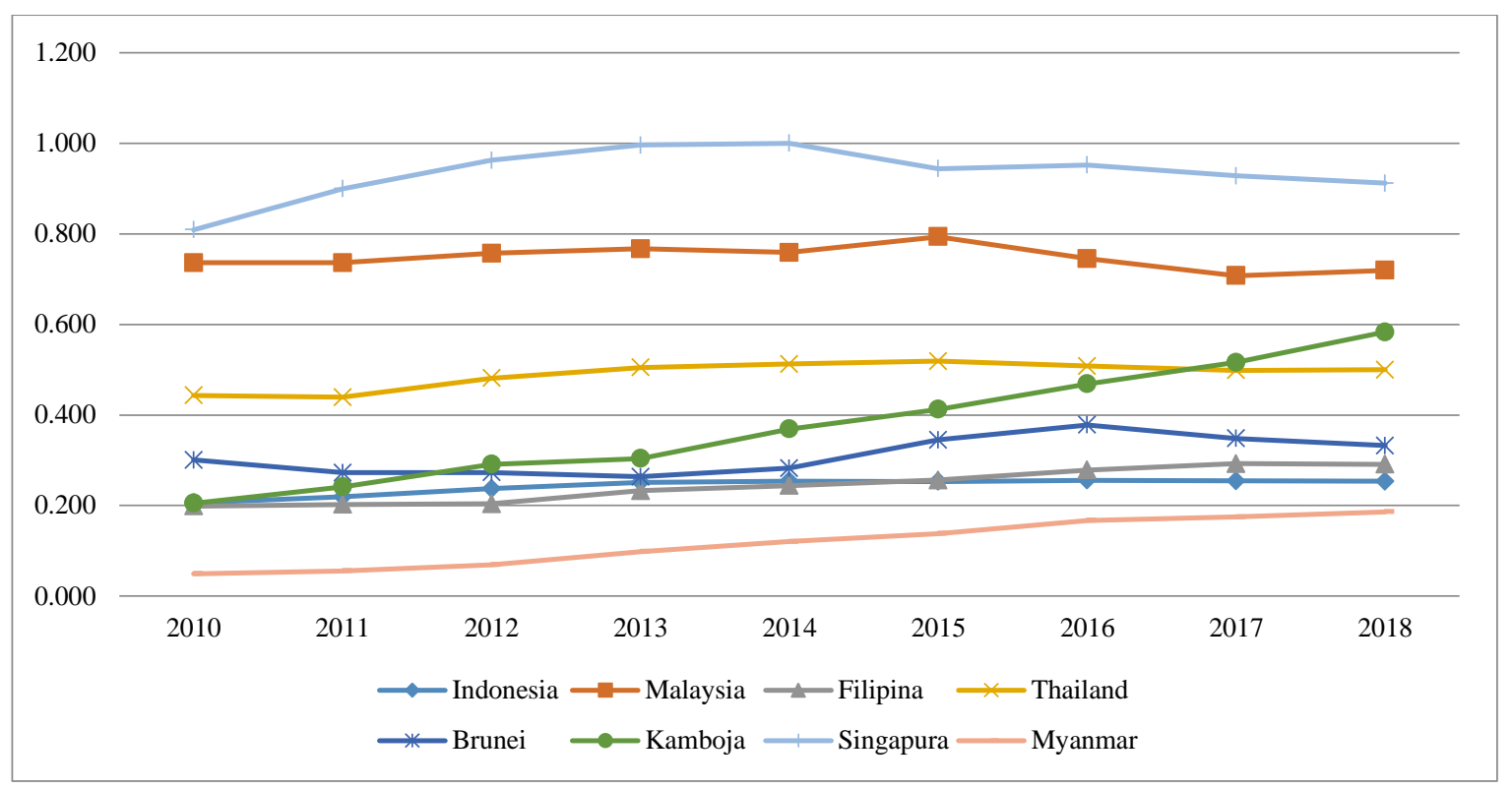

Figure 4. Dimensions in the Use of Banking Services in ASEAN in 2010-2018

The country that has the highest dimension of banking service used is Singapore with a value of $0.8-1$, while the country that has the lowest cost of the banking service use dimension in ASEAN is Myanmar with a value of 0.04-0.18 (Figure 4). The small proportion of the use of banking services in Myanmar is also due to the low dimensions of the availability of banking services in the country.

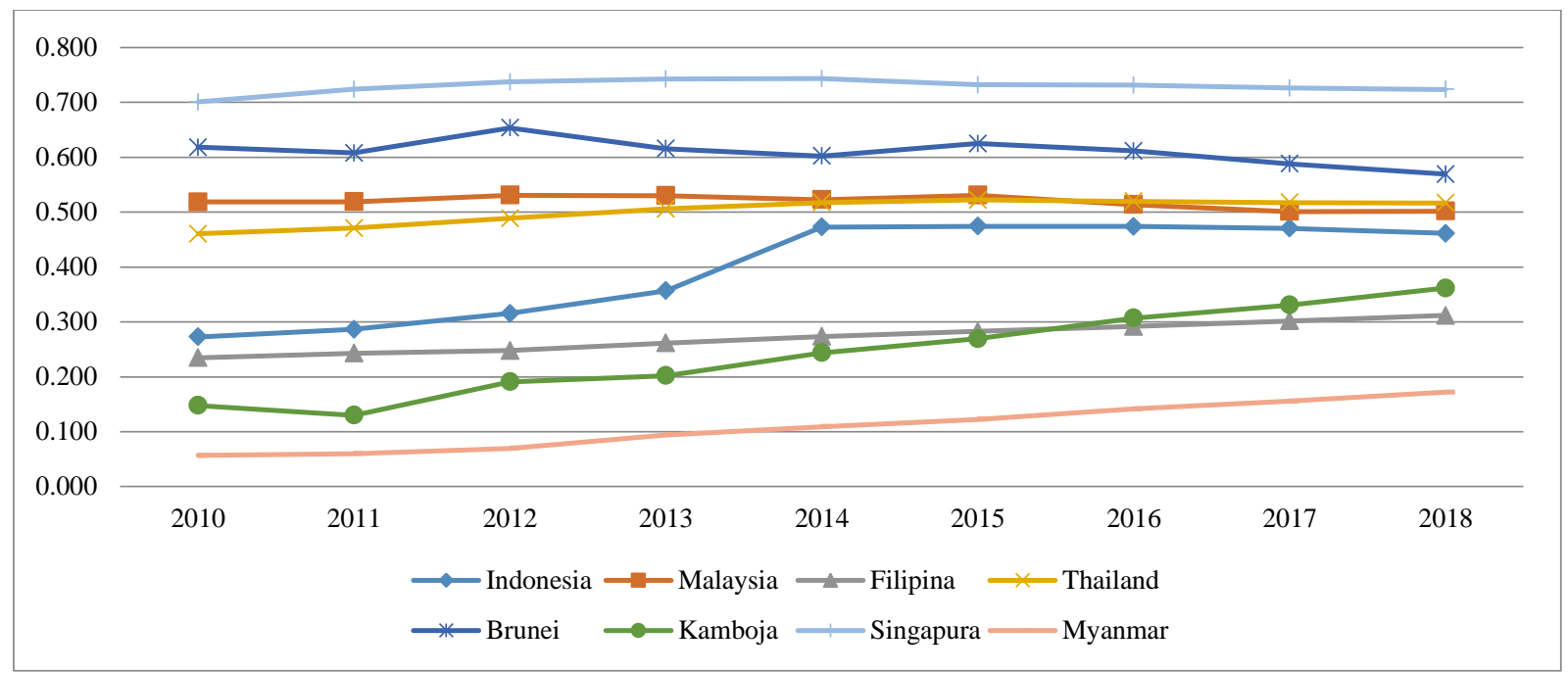

Figure 5. Inclusive Financial Index Trend in ASEAN in 2010-2018

Some countries in ASEAN that have relatively high financial inclusion index values are Malaysia, Brunei, and Singapore (Figure 5). The high index of financial inclusion in the three countries shows that there is a 
convenience for residents in these countries to access financial services. Meanwhile, the financial inclusion index in the Philippines, Cambodia, and Myanmar is included in the low category.

\subsection{Relationship of Financial Inclusion Indices with Achievement of SDGs in ASEAN}

Countries in ASEAN are committed to realizing the SDGs, especially the goal of eradicating poverty. All countries in ASEAN are trying to improve the economic work of the population, including through improving banking access services for the poor. Easier access to finance will have an impact on the community to improve living standards. More and more people are taking part in moving the wheels of the economy and enlarging the country's opportunities to increase income so that the primary goal of the SDGs to reduce poverty can be achieved. The relationship of general financial indexes with debt in ASEAN can be seen in Table 1.

Table 1. Correlation of Financial Inclusion Index with Poverty Rate in ASEAN

\begin{tabular}{cc}
\hline Dependent Variable: POVERTY & Simple Regression \\
\hline A constant & 29.47240 \\
Standard error & 1.193776 \\
t-statistics & 24.68839 \\
Probability & 0.0000 \\
Financial Index & \\
A constant & -40.95875 \\
Standard error & 2.588384 \\
t-statistics & -15.82406 \\
Probability & 0.0000 \\
R2 & 0.744353 \\
f-statistics & 250.4009 \\
Prob (f-stat) & 0.000000 \\
Durbin-Watson stat & 0.394897 \\
\hline
\end{tabular}

Source: Data Processed, 2019

The relationship of financial inclusion index to poverty as an essential aspect in achieving SDGs in ASEAN is interpreted that the financial inclusion index has a significant negative effect on poverty (Table 1). This means that if financial inclusion improves, poverty levels will decrease. This finding is in line with the results of similar research by Chibba (2009), Sarma and Pias (2012), Demirgüç-Kunt (2013), Pradhan et. al. (2014), Ghauri and Wang (2017), and Odusola (2019). In ASEAN countries where poverty levels are still high, it is necessary to increase financial inclusion.

Poverty rates in Malaysia, Brunei, and Singapore are meager, and the population has high access to financial services. Myanmar is a poor country in ASEAN, and financial inclusion is still low, so it needs collective efforts to improve financial access, including microfinance, so that population productivity increases. Financial inclusion will benefit the poor. The availability of financial services helps the poor get health insurance for education, health, and other needs that will improve the quality of life of the poor. Apart 
from aiming at eradicating poverty, the SGDs also enhance the quality of education, health, and infrastructure. Inclusive development and increased financial inclusion will directly realize the SGDs (Grohmann et. al. 2018, Donaires, et. al. 2019, Datta \& Singh, 2019).

Financial inclusion helps small and medium business owners gain access to credit more easily (Kumar, 2013; Nasir, 2019). Excellent financial services will encourage economic independence for the poor. Improvement of financial assistance can be made through the development of microfinance institutions that can directly touch the activities of rural populations. In addition to poverty alleviation, the financial inclusion dimension also relates to SGDs in the aspects of education, health, and infrastructure. T-statistic test about the effect of each independent variable individually on the dependent variable.

Table 2. Results of the t-statistical test Determinants of Financial Inclusion Indexes in ASEAN

\begin{tabular}{cccc}
\hline Variable & Regression coefficient & Prob. & Prob Standard. \\
\hline Literacy Numbers & 0.003880 & 0.0871 & 0,10 \\
Road infrastructure & 0.027438 & 0.1964 & 0,05 \\
GDP per capita & 0.236623 & 0.0000 & 0,05 \\
\hline
\end{tabular}

Source: Data Processed, 2019

The results of the statistical analysis related to the determinants of financial inclusion (Table 2) show that the Literacy Rate has a positive and significant effect on economic integration in ASEAN with a significance level of $10 \%$. This finding is in line with research by Sarma and Pias (2011), Park and Mercado (2015), Uddin et. al., (2017), Abel et. al., (2018) and Le et. al., (2019). Efforts to achieve the SGDs also affect financial inclusion, and vice versa. Inclusive finance will even realize the SDGs. Efforts should be made to improve the quality of education, especially in poorer countries (Singer-Brodowski, 2018). Meanwhile, the development of road infrastructure has a positive but not significant effect on financial inclusion in ASEAN at a 5\% significance level.

The value of GDP per capita has a positive and significant effect on financial inclusion in ASEAN at significance level of 5\%. These results are in line with research by Park and Mercado (2015), Uddin et. al., (2017), David et. al. (2018), Abel et. al., (2018), Neaime and Gaysset (2018), and Padda et. al. (2018). Financial inclusion contributes to increased revenue, which means realizing SGDs (Donaires et. al. 2018). Likewise, increasing population income will increase financial inclusion in ASEAN.

\section{Conclusion}

The Financial Inclusion Index on the achievement of the SDGs in the aspect of poverty in ASEAN has a negative and significant relationship with poverty levels. Policies to increase financial inclusion will have a direct impact on poverty reduction. The availability of financial services makes it easy for the poor to get access to education, health, and other needs that will improve their quality of life. Financial inclusion also increases business credit access for small and medium businesses.

Literacy rates have a positive and significant impact on financial inclusion in ASEAN. The better the literacy rate of a country, the better their access to financial institutions will be. The level of income of the people in ASEAN has a positive and significant effect on financial inclusion. The higher the level of income per capita of a country, the greater access the population has to financial institutions. Countries in ASEAN, especially those who are poor, need to adopt policies to expand financial access so that they can directly realize the SGDs, which are globally targeted to be achieved in 2030. 


\section{References}

Abel, S., Mutandwa, L., \& Le Roux, P. (2018). A Review of Determinants of Financial Inclusion. International Journal of Economics and Financial Issues, 8(3), 1-8. https://ideas.repec.org/a/eco/journ1/2018-03-1.html

Abdullahi, I. B., \& Fakunmoju, S. K. Financial Inclusion And Small And Medium Enterprises Contribution To Sustainable Economic Growth In Nigeria. http://www.jsd-africa.com/Jsda/Vol19No2Summer2017/PDF/Financial\%20Inclusion\%20and\%20Small\%20and\%20Medium_Ibrahim\%20Bello.pdf

Ali, I., \& Son, H. H. (2007). Measuring inclusive growth. Asian Development Review, $24(1), 11$. https://doi.org/10.1177/ 002795011924700110

ASEAN, 2019, About ASEAN, www.asean.org

Chibba, M. (2009). Financial inclusion, poverty reduction and the millennium development goals. The European Journal of Development Research, 21(2), 213-230.https://doi.org/10.1057/ejdr.2008.17.

Datta, S. K., \& Singh, K. (2019). Variation and Determinants of Financial Inclusion and association with Human Development: A Cross Country Analysis. IIMB Management Review. https://doi.org/10.1016/j.iimb.2019.07.013

David, O. O. K., Oluseyi, A. S. \& Emmanuel, A. (2018). Empirical Analysis of the Determinants of Financial Inclusion in Nigeria: 1990-2016. Journal of Finance and Economics, 6(1), 19-25. https://doi.org/10.12691/jfe-6-1-3

Demirgüç-Kunt, A., Honohan, P., \& Beck, T. (2008). Finance for all?: Policies and Pitfalls in Expanding Access. World bank. https://siteresources.worldbank.org/INTFINFORALL/ Resources/ 4099583-1194373512632/FFA_book.pdf

Demirgüç-Kunt, A., \& Klapper, L. (2013). Measuring financial inclusion: Explaining variation in use of financial services across and within countries. Brookings Papers on Economic Activity, 2013(1), 279340.https://doi.org/10.1353/eca.2013.0002

Donaires, O. S., Cezarino, L. O., Caldana, A. C. F., \& Liboni, L. (2019). Sustainable development goals-an analysis of outcomes. Kybernetes, 48(1), 183-207. https://doi.org/10.1108/K-10-2017-0401

Ghauri, P. N., \& Wang, F. (2017). The Impact of Multinational Enterprises on Sustainable Development and Poverty Reduction: Research Framework. In International Business \& Management (pp. 13-39). Emerald Publishing Limited. https://doi.org/ 10.1108/S1876-066X20170000033002

Grohmann, A., Klühs, T., \& Menkhoff, L. (2018). Does financial literacy improve financial inclusion? Cross country evidence. World Development, 111, 84-96. https://doi.org/10.1016/j.worlddev.2018.06.020

Kumar, N. (2013). Financial inclusion and its determinants: evidence from India. Journal of Financial Economic Policy, 5(1), 4-19.https://doi.org/10.1108/17576381311317754.

Kuri, P. K., \& Laha, A. (2011). Financial inclusion and human development in India: an inter-state analysis. Indian Journal of Human Development, 5(1), 61-77. http://www.irjmsh.com/abstractview/7533

Le, T. T., Dang, N. D. L., Nguyen, T. D. T., Vu, T. S., \& Tran, M. D. (2019). Determinants of Financial Inclusion: Comparative Study of Asian Countries. Asian Economic and Financial Review, 9(10), 1107.https://doi.org/10.18488/journal.aefr.2019.910.1107.1123

Nanda, K., \& Kaur, M. (2016). Financial inclusion and human development: a cross-country evidence. Management and Labour Studies, 41(2), 127-153. https://doi.org/10.1177/0258042x16658734.

Nasir, M. A., Huynh, T. L. D., \& Tram, H. T. X. (2019). Role of financial development, economic growth \& foreign direct investment in driving climate change: A case of emerging ASEAN. Journal of environmental management, 242, 131-141. https://doi.org/10.1016/j.jenvman.2019.03.112

Neaime, S., \& Gaysset, I. (2018). Financial inclusion and stability in MENA: Evidence from poverty and inequality. Finance Research Letters, 24, 230-237.Available at: https://doi.org/10.1016/j.frl.2017.09.007.

Odusola, A. (2019). Growth-Poverty-Inequality Nexus: Toward a Mutually Inclusive Relationship in Africa. In African Economic Development (pp. 157-182). Emerald Publishing Limited. https://doi.org/10.1108/978-1-78743-783820192010

Donaires, O. S., Cezarino, L. O., Caldana, A. C. F., \& Liboni, L. (2019). Sustainable development goals-an analysis of outcomes. Kybernetes, 48(1), 183-207.www.emeraldinsight.com, https:// doi.org/10.1108/K-10-2017-0401

Padda, I. U. H., \& Hameed, A. (2018). Estimating multidimensional poverty levels in rural Pakistan: A contribution to sustainable development policies. Journal of cleaner production, 197, 435-442. https://doi.org/10.1016/j.jclepro.2018.05.224 
Park, C. Y., \& Mercado, R. (2015). Financial inclusion, poverty, and income inequality in developing Asia. Asian Development Bank Economics Working Paper Series, (426).https://doi.org/10.2139/ssrn.2558936

Pradhan, R. P., Arvin, M. B., Hall, J. H., \& Bahmani, S. (2014). Causal nexus between economic growth, banking sector development, stock market development, and other macroeconomic variables: The case of ASEAN countries. Review of Financial Economics, 23(4), 155-173. http://dx.doi.org/10.1016/j.rfe.2014.07.002

Sarma, M., \& Pais, J. (2011). Financial inclusion and development. Journal of international development, 23(5), 613628. https://doi.org/10.14707/ajbr.160020

Singer-Brodowski, M., Grossmann, K., Bartke, S., Huning, S., Weinsziehr, T., \& Hagemann, N. (2018). Competencyoriented education for sustainable development: Lessons from five courses on energy poverty. International Journal of Sustainability in Higher Education, 19(7), 1299-1316. https://doi.org/10.1108/IJSHE-12-2017-0223

Suresh, P., \& Johnson, L. R. (2015). The post-2015 agenda: From Millennium Development Goals (MDGs) to Sustainable Development Goals (SDGs). International Journal of Current Research and Review, 7(15), 62. http://www.ijcrr.com/uploads/488_pdf.pdf

Todaro, M. P., \& Smith, S. C. (2017). Economic Development, ND: Pearson.

Uddin, A., Chowdhury, M. A. F., \& Islam, M. N. (2017). Determinants Of Financial Inclusion In Bangladesh: Dynamic Gmm \& Quantile Regression Approach. The Journal of Developing Areas, 51(2), 221-237. https://doi.org/ 10.1353/jda.2017.0041.

UNDP. (2016). SDGs Booklet. Retrieved from www.undp.org.

World Bank, 2018, Financial Inclusion, https://www.worldbank.org. 